\title{
Gaining Competitive Advantage through Marketing Strategies in Container Terminal: A Case Study on Shahid Rajaee Port in Iran
}

\author{
Hossein Cheraghi \\ School of Management, Sharif University of Technology-International Campus \\ E-mail: cheraghi_353@yahoo.com \\ Alireza Abdolhosseini Khaligh \\ School of Management, Sharif University of Technology-International Campus \\ E-mail: arkhalig@yahoo.com
}

Abbass Naderi

School of Management, Sharif University of Technology-International Campus

E-mail: asramco@gmail.com

Alireza Miremadi (Corresponding author)

Assiatant Marketing Professor \& MBA Director

School of Managemn, Sharif University of Technology-International Campus

Amir Kabir Square, Kish Island, Iran

Tel: 98-764-442-2299 Ext. 326

E-mail: ar.miremadi@Sharif.edu

Received: October 2, 2011

Accepted: December 12, 2011

Published: February 1, 2012

doi:10.5539/ibr.v5n2p179

URL: http://dx.doi.org/10.5539/ibr.v5n2p179

\begin{abstract}
Shahid Rajaee port complex at Bandar Abbas is the country's principal gateway for containerized cargo. It has emerged as a leading regional commercial center and a world class business environment. It has now become the logical place to do business in the Middle East, providing investors with a unique value added platform. Ports have a significant role in today's networked business environment. They are being regarded as hubs that are part of various logistics systems. The very essence of seaport is to link maritime networks and land network. These networks for the port are means of analyzing its competitiveness. The objective of this study is to find out the main factors which impact on competitiveness of container port in Shaied Rajaee. Port and enable it to suggest and apply the profound marketing strategy to get the huge load in this port. Based on our findings by employing the factor analysis is to reveal the vital competitiveness of the port. It reveal that that port strategy and policy, port logistics, hinterland condition, availability, shipping maritime service, port Regional center, shipping agreement and port service and connectivity are determining factors in the shahid Rajee port in Iran.
\end{abstract}

Keywords: Port competitiveness, Shipping line, Marketing strategy, Shaid Rajee, Factor analysis, Iran

\section{Introduction}

Port investment is continuous in most parts of the world, to cope with the year-on-year growth in container trade. The Middle East has seen strong container port demand growth, and virtually all ports have programmes to increase capacity and/or their capability to handle larger vessels.

\subsection{Shahid Rajaee Port}

The market environment in which seaports operate is changing. Ports are confronted with changing economic and logistics systems. Port authorities and port management effectively to market dynamics whose objectives are 
significantly economic, are forced to re-assess their role and related governance structures.

The coastline of the Islamic Republic of Iran borders the Persian Gulf, the Gulf of Oman, and the Caspian Sea. All three sea areas have important ports, Iran's largest port, Bandar Abbas, is located on the Strait of Hormuz, the narrow passage separating the Persian Gulf and the Gulf of Oman. These sea areas are of high significance for the commercial navigation: the Gulf Areas due to the large hydrocarbon reserves with increasing vessel traffic, especially tanker traffic and the Caspian Sea due to the potential growth of transport through the "North-South corridor". Iran's Commercial Ports General Master Plan - Phase II covers the following eight major, and four minor ports.

Shahid Rajaee port complex at Bandar Abbas has 1,050 m of container quay, equipped with two panamax and eight post-panamax container gantry cranes, the most recent five of which were installed in 2004-05. In 2004, the handling of feederships was transferred to general cargo quays, served by mobile cranes. The container terminal is operated by Tidewater Middle East, of which the government's Ports and Shipping Organization owns 45.76 per cent. Under the country's fourth five-year plan, the government's shares are to be sold to the private sector by 2010 . A second container terminal, of $70 \mathrm{~h}$, is due to open in 2008 , with $850 \mathrm{~m}$ of quay, $17 \mathrm{~m}$ depth alongside and eight super post-panamax container gantry cranes. A second phase is intended to add $140 \mathrm{~h}$ and $2,050 \mathrm{~m}$ of quay.

\subsection{Capacity Forecasts of Middle East}

Based on quantification of port and terminal investment plans, capacity forecasts for the Middle East are detailed by port range and port in below Table. Container handling capacity at Middle East ports is set to increase by 148 per cent over 2006-15 to $69.6 \mathrm{~m} \mathrm{TEU/year.}$

According to the anticipated course of port investment, capacity at ports on the Persian Gulf and Gulf of Oman will grow by 147 per cent over 2006-15 to $48.1 \mathrm{~m} \mathrm{TEU/year.} \mathrm{New} \mathrm{terminal} \mathrm{development} \mathrm{at} \mathrm{Jebel} \mathrm{Ali} \mathrm{is} \mathrm{expected} \mathrm{to} \mathrm{boost}$ capacity at the Dubai ports by 141 per cent to $26.5 \mathrm{~m}$ TEU/year over this period. Abu Dhabi and Bahrain are both set to increase capacity by a factor of four with the planned development of new ports at Taweelah and Mina Khalifa respectively, whilst Kuwait's planned new Bubiyan terminal is expected to contribute to a 3.9-fold growth in capacity.

On the Arabian Sea and Gulf of Aden range, a 184 per cent increase to $9.9 \mathrm{~m}$ TEU/year will be generated by anticipated investment programmes over 2006-15. Salalah will remain the dominant port in the range with a 173 per cent rise in capacity to $6.6 \mathrm{~m}$ TEU/year, but the largest increase will come from Djibouti's planned new 1.6 TEU/year capacity terminals at Doraleh.

Ports on the Red Sea will see a 128 per cent increase in capacity over 2006-15, to $11.58 \mathrm{~m} \mathrm{TEU} /$ year, if investment proceeds as anticipated. Saudi ports - in particular Jeddah - will remain pre-eminent, with 119 per cent growth to $7.7 \mathrm{~m} \mathrm{TEU/year,} \mathrm{but} \mathrm{strong} \mathrm{increases} \mathrm{are} \mathrm{also} \mathrm{planned} \mathrm{in} \mathrm{Jordan,} \mathrm{Egypt} \mathrm{and} \mathrm{Sudan.}$

\section{Literature Review}

\subsection{Port and Shipping}

There is an expanding interest in the changing role of ports as a result of the globalization of production and distribution (K. Bichou, 2004; Carbone, 2003; De Martino, 2003; Gray, 2004; Notteboom, 2005; Robinson, 2002; Rodrigue, 2005). Customarily, ports are taken into account to act as an interface between ships and shore by preparing shelter and berthing space, temporary storage and the supply of superstructure and infrastructure for cargo operation and movement within port. So, their functions and roles are seen as a standalone with very little attention to the importance of the other parts of the supply chain. On this basis, the main part of research in the area has been on the efficiency and performance of seaports and container terminals (Cullinane, 2002; Heng, 2005; Tongzon, 2005). Currently, ports are considered to have a new role to fulfill in the era of globalization. The development of global supply chains changes ports' role towards efficient distribution of products across supply chains as opposed to performance in loading, unloading of ships and berth availability. In this new role, the port is considered as part of a cluster of organizations in which different logistics and transport operators are involved in bringing value to the final consumers. In order to be successful, these channels require gaining a higher degree of coordination and cooperation (De Souza, 2003; Panayides, 2007; Song, 2007). There are substantial gains to be made from technology investment with the insurance that the productivity gains from technology investments are manifested in cost savings to port users. In addition, there are also consequential gains from implementing programs on customer and stakeholder relationships and from introducing value-added services. For example, an investment in a more advanced information technology to reduce turnaround times for ships can provide gains for shipping lines which can be passed onto shippers in terms of lower freight rates. More must be done to implement programs for port integration in the supply chain while maintaining more flexibility and responsiveness to the preferences of shipping 
lines. In spite of their pioneering work of measuring the relationship, their findings do not provide balanced views between the service providers and the actual service users. The concept of supply chain is complex and consists of a number of parties involved in the delivery and in adding value to the final product. A gap in perceptions is potentially important as it indicates either the possibility of over-emphasis on areas that customers do not value, or a potential shortfall in provision of services in areas they do. There some important factors which effect on port importance such as having Confidence in port schedules, frequency of calling vessels, variety of shipping routes, accessibility of port (Pearson, 1980), navigation distance, hinterland nearness, connectivity to ports, port facilities, availability of port, port tariffs(Willingale, 1981), average waiting time in port, port service capacity(Collison, 1984), calling frequency, tariffs, accessibility in port schedules, port congestion, inter-linked transportation networks(Slack, 1985), port costs, frequency of calling vessels, port reputation and/or loyalty, ship direct calling, experience of cargo damage(Brooks, 1984, 1985). Having loading and unloading facilities for large and/or odd-sized freight, having low freight handling shipments, providing a low frequency of loss and damage, equipment availability, offering convenient pick-up and delivery times, providing information concerning handling, offering assistance in claims handling, offering flexibility in meeting special handling requirements(P. Murphy, Dalenberg, D., Daley, J.,, 1988, 1989, 1991; P. Murphy, Daley, J., Dalenberg, D.,, 1992).Other approaches which have been proposed have divided effective factors in port industry and shipping lines by two groups: Internal and External. Internal factors like service level, availability facility capacity, status of the facility, port operation policy. External factors like international politics, change of social environment, trade market, economic factors, features of competitive ports, functional changes of transportation and materials handling(Peters, 1990), geographical location, hinterland networks, availability and efficiency of transportation, port tariffs, stability of port, port information system(UNCTAD, 1992), port facilities, inland transportation networks, container transport routes(McCalla, 1994), geographic location of ports, inland railway transportation, investment of port facilities, stability of port labor(Starr, 1994), port tariffs, safety handling of cargoes, confidence in port schedules (Tengku, 1995), custom service, rapidness, simple documents in port, cargo damage and skills of port (Chiu, 1996).

\subsection{Port Competitiveness}

The verification of port competitiveness has fundamentally focused on port selection criteria. In the 1980s,(Collison, 1984; Pearson, 1980; Slack, 1985; Willingale, 1981) purposed various components of port selection which covered Europe, America and South-east Asia. Moreover in the 1990s,(Brooks, 1985; McCalla, 1994; P. Murphy, Dalenberg, D., Daley, J.,, 1988, 1989, 1991; P. Murphy, Daley, J., Dalenberg, D.,, 1992; Peters, 1990; UNCTAD, 1992) exposed varying analytical dimensions and major factors influencing them. Studies in the 1990s included American studies of the geographic location of ports, inland railway transportation, investment in port facilities and the stability of port labor(Starr, 1994).

In 1995, Tengku's PhD thesis at Cardiff University entitled 'Marketing of freight liner shipping services with reference to the far-East-Europe trade: a Malaysian perspective' highlighted port tariffs, safe handling of cargoes, confidence in port schedules and port service. A year later at the same institution Chiu's PhD thesis 'Logistics performance of liner shipping in Taiwan' noted that customs service, rapidity of processing, simplicity of documentation in port, cargo damage and skills of port labor influenced port competitiveness (Table 4). Later,(Malchow, 2001) analyzed the flow of four commodities in eight major US ports. Moreover, they extended their studies in 10 major US ports by incorporating additional attributes finding that the most significant characteristic of a port was its location(Malchow, 2001). Recently,(Heng, 2005; Tongzon, 2005) suggested eight determining factors of port competitiveness and(K. Bichou, Gray, R., 2005) argued that port competition will shift from the institutional, functional and/or spatial levels to channel management.

\section{Research Methodology}

\subsection{Identifying Factors Effect on the Competitiveness of the Port and Shipping Lines}

As what mentioned, in this research we face with complexity of components. We have extracted components from different models and articles and join them to setup the base of our research. At the end, we start the analysis with 50 components. (Table 2)

\subsection{Data Collection}

We have conducted face-to-face interviews with participants of this research in April and May 2011, at first with 85 useable responses from 94 questionnaires were distributed in Shahid Rajaee different sections to coordinate the pilot test of our research. And then our research main tests were conducted with 320 useable responses from 343 questionnaires. Respondents' gender, age, Educational Level, job profiles have been illustrated in Table 1 to Table 4 in May 2011. Attitudes on each of the variables has been evaluated using five-point Likert scales attached firmly by the agreement level of each question with point of $1=$ very poor and $5=$ excellent. 


\subsection{Data Analysis}

\subsubsection{Reliability of Pilot Test, Calculation of Sample Size (N)}

A reliability test, based on Cronbach's Alpha, is used to test the internal consistency of questionnaire responses. We have used Cronbach's Alpha ( $\alpha$ ) to show the reliability of pilot test. The Cronbach's Alpha of

pilot test is 0.934 . It shows that the reliability of this test is high.

\subsubsection{Reliability of Main Test}

As we mentioned above, the research is conducted with considering the population upper than 294. The Cronbach's $\alpha$ of main test of our research is 0.843 . Since the Cronbach's $\alpha$ is more than 0.7 , it indicates our research reliable and the research questionnaire responses have high internal consistency (Cronbach, 1951; Nova'k, 2004; Ware, 1998)

\subsubsection{Factor Analysis Results}

Factor analysis has been employed as an appropriate methodology to synchronously validate measurements in port and transport studies (Blanc, 1998; Ha, 2003; Kent, 2001; Lu, 1999; Tracey, 2004). Fundamentally, it is divided by two approaches. The first approach of factor analysis, exploratory factor analysis, is used to explore and survey purposes to establish trends and variable structures and the second, confirmatory factor analysis, is used for evaluation and analysis. This study adopted the second approach, first of all, to explore and categorize the variables and then form clusters of components and the evaluation structure.

In the first step of this research, KMO and Bartlett's Test is used to know whether it is possible to employ factor analysis to reduce attributes of the research. The Kaiser-Meyer-Olkin measure of sampling adequacy figure is 0.732 higher than 0.6 and near to 1 . It shows either the number of respondents is adequate. The quantity of Bartlett's sig. is 0.000 less than 0.05 . It indicates factor analysis is appropriate for to identify the model of factors. Totally, these two outputs demonstrate we have permission to run factor analysis. In the next outcome, with principle component analysis, we find that the quantity of port safety and security attribute in extraction method is 0.454 less than 0.5 . It shows this attribute should be eliminated for factor reduction. The factor analysis is run for the second time and the outcome shows the port privatization should be omitted that's why it is 0.488 less than 0.5 . The factor analysis is run for the third time and all the attributes quantity is higher than 0.5. So we should terminate factor reduction and go to next outcome. The third outcome is total variance explained. In this outcome, the Initial Eigenvalues part determines that 16 factors will remain and the rest are omitted from the analysis. The Rotation Sums of Squared Loadings part in our research indicates 16 extracted factors with varimax rotation have Initial Eigenvalues higher than 1.0 and can remain in the analysis. These 16 factors interpret $67 \%$ of variables variance. We used varimax rotation to normalize the percentage of variance among factors. For example, the percentage of variance for first factor without rotation is 14.880 while it is normalized to 6.235 with varimax rotation.

The other outcome which is the main part of our analysis is the Rotated Component Matrix which contains factor loadings of each variable in remained factors after rotation. In accordance with what we mentioned in previous paragraph, our research has 16 factors and 48 variables. It means we should have had 16 factors with 3 attributes for each one, but we didn't do it. For improvement, we combine each of 2 components to build 1 factor with 6 subsets. Thus, our research has 8 factors.

Insert Table 3 Here

In Rotated Component Matrix, we try to categorize each factor with 3 loadings with higher absolute value. The higher value of factor loading has the more effect on total variance. With consideration to the factor analysis on 50 variables, 8 factors are identified as main factors of our research. These eight factors are: 1 . Port Strategy and Policy; 2. Port Logistics; 3. Hinterland Condition; 4. Availability; 5. Shipping Maritime Service; 6. Port Regional Service; 7. Shipping Agreement; 8. Port Service and Connectivity.

Insert Table 4 Here

- The factor analysis shows that the variables Reliability of Schedules in Port, Port Productivity, Recognition and Reputation of Port, Port Strategic Planning, Port Marketing Strategy, and Flexibility of Rules \& Regulation are categorized under the factor of Port Strategy and Policy.

- The variables Efficient Inland Transport Network, Inland Transportation Cost, Port Software Capacity, Sophistication Level of Shipping Information Software and System, Port Infrastructure and Superstructure, Port Community are grouped under the factor of Port Logistics.

- The variables Hub \& Spokes Network, Deviation from Main Trunk Route, Port Congestion, Reliability of Schedules in Shipping, Ship Safety and Security, Frequency of Large Container Ship Calling are grouped under the 
factor of Hinterland Condition.

- The variables Service Differentiation, Availability of Vessel Berth on Arrival in Port, Well Articulated Logistics Flow and Added-Value Operation, Port Accessibility (Navigation Distance), Ship Capacity and Size, and Port Competition are the clusters of the factor of Availability.

- The other group of variables are Frequency of Ships Calling and Diversify of Ship Route, Frequency of Cargo Loss and Damage, Number of Direct Shipping Lines of Ocean-Going Vessel, Water Depth in Approach Channel and at Berth, Port Capacity and Size, and Port Cluster which form the factor of Shipping Maritime Service. (Table 3)

- The variables Port Location (Geographically), Special Economic Zone (SEZ) Free Economic Zone (FEZ), Cost for Cargo Handling, Transfer and Storage, Inter-Modal Link, Cost Related Vessel Entering are the clusters of the factor of Port Regional Center. (Table 3)

- Trade and Commerce Policy, Mutual Agreement of Port Users, Adaptability to the Changing Market Environment, Level of Service for Fresh Water, Bunkering, Ship products and Repair, Free Dwell Time on the Terminal, and Maritime Dependence Factors (MDF) are the loadings of the factor of Shipping Agreement. (Table 3)

- The variables Customs Clearance System, 24 Hour a Day, Seven Days a Week Service, Zero Waiting Time Service, Level of Ship Entrance and Departure, Hinterland Access, and Professionals and Skilled Labors in Shipping Operation are categorized under the factor of Port Service and Connectivity. (Table 3)

\subsubsection{Reliability for Factors}

A reliability test, based on Cronbach's Alpha, is used to test the each internal consistency of each construct (factor) and the result shows all of 8 factors have internal consistency. Port Strategy and Policy, Port Logistics, and Availability have the $\alpha$ values higher than 0.7 so their consistency is high, but the Cronbach's Alpha of Port Regional Service, Shipping Agreement, Port Service and Connectivity, Hinterland Condition, and Shipping Maritime Service are between 0.5 and 0.7 which shows normal consistency..(Cronbach, 1951; Nova'k, 2004; Ware, 1998).

\section{Findings}

As we mentioned in analysis section, now it is time to design main structured model of our research.

Insert Figure 2 Here

\subsection{Correlation of Factors}

We continue our research with analyzing the correlation of factors to measure the association among them. Satisfying this scope, we employ Pearson Correlation Coefficient and Spearman Correlation Coefficient. The correlation coefficient, which ranges from -1 to +1 is both a measure of the strength of the relationship and the direction of the relationship. Pearson Correlation Coefficient $(\mathrm{r})$ is calculated by following equation:

The correlation coefficient, which ranges from -1 to +1 is both a measure of the strength of the relationship and the direction of the relationship. A correlation coefficient of 1 describes a perfect relationship in which every change of +1 in one variable is associated with a change of +1 in the other variable. A correlation of -1 describes a perfect relationship in which every change of +1 in one variable is associated with a change of -1 in the other variable. A correlation of 0 describes a situation in which a change in one variable is not associated with any particular change in the other variable. In other words, knowing the value of one of the variables gives you no information about the value of the other.

The following findings have gained from verifying correlation between factors via Pearson Correlation Coefficient and Sig.

\section{Insert Table 5 Here}

- In according to Pearson Correlation results, the highest correlation is between Port Logistics and Availability at the 0.01 level of Pearson Sig. The Correlation Coefficient between them is 0.590 .

- In according to Pearson Correlation results, Port Strategy and Policy and Port Regional Service have correlation at the 0.05 level of Pearson Sig. The Correlation Coefficient between them is 0.131 .

- As Pearson Correlation results shows, there is no correlation between Port Logistics and Sipping Maritime Service.

- As Pearson Correlation results shows, there is no correlation between Hinterland Condition and Port Regional Service.

- As Pearson Correlation results shows, there is no correlation between Availability and Port Regional Service. 
- In according to Pearson Correlation results, Shipping Maritime Service and Shipping Agreement and Port Service and Connectivity have correlation with all other factors at the 0.01 level of Pearson Sig.

\subsection{Friedman Test Result}

The Friedman test is applicable to problems with repeated-measures designs or matched-subjects designs. Friedman test is used to analyze the equality of preferences of components. In this research, we make an attempt to find out whether the preferences of 8 factors are equal or at least 2 factors have different preferences. We analyze the Relation between differences via $\mathrm{H}_{0}$ and $\mathrm{H}_{1}$ test. The interpretation of $\mathrm{H}_{0}$ is the equality of preferences of factors, and the interpretation of $\mathrm{H}_{1}$ is the difference at least between two factors. In according Friedman test, since the Sig. is less than 0.05 , so the $\mathrm{H}_{0}$ is not acceptable and the effect of all the factors on competitiveness of Shahid Rajaee port and shipping is not the same. Friedman test points that the factor of Port Regional Service is the most important factor and has the greatest effect on competitiveness of Shahid Rajaee port and shipping.

The classification of factors as point of preference in accordance with Freidman test is as the following:

\section{- Port Regional Service}

- Port Service and Connectivity

- Shipping Agreement

- Shipping Maritime Service

- Hinterland Condition

- Port Logistics

- Availability

- Port Strategy and Policy

The main component from the clusters of Port Regional Service which has the greatest effect on competitiveness of Shahid Rajaee Port and Shipping is the Port Location. The second important component in competitiveness of the port and shipping is Competitive Advantage of Port in Ships Route. It is one of the clusters of port service and connectivity.

\section{Conclusion}

This paper contribute the first study of port competitiveness in Iran, although the existing literature has pointed out the importance of competitiveness for port but empirical work on this issue is very limited in Asia. The purpose of this paper is to determine the components and evaluate the factors which have the high impact on the competitiveness of Shahid Rajaee port and shipping lines. The identified competitiveness of attributes of shahid Rajaee port contains Port Strategy and Policy; Port Logistics; Hinterland Condition; Availability; Shipping Maritime Service; Port Regional Service; Shipping Agreement; and Port Service and Connectivity. It enables port manager to draw practical marketing strategy by knowing these attributes and absorb the huge useful terrific in this port.

\section{References}

Bichou, K. (2004). A logistics and supply chain management approach to port performance measurement. Maritime Policy \& Management, 31(1), 47-67. http://dx.doi.org/10.1080/0308883032000174454

Bichou, K., Gray, R. (2005). A critical review of conventional terminology for classifying seaports. Transportation Research Part A: Policy and Practice, 39(1), 75-92. http://dx.doi.org/10.1016/j.tra.2004.11.003

Blanc, L., Wyckoff, P. (1998). A strategic success factor analysis of the New Orleans vessel traffic service. Transportation Journal, 38(3), 44-50.

Brooks, M. (1984). An alternative theoretical approach to the evaluation of liner shipping-Part 1. Situational factors. Maritime Policy and Management, 11(1), 35-43. http://dx.doi.org/10.1080/03088838400000032

Brooks, M. (1985). An alternative theoretical approach to the evaluation of liner shipping - Part 2: choice criteria. Maritime Policy and Management, 12(2), 145-155. http://dx.doi.org/10.1080/03088838500000050

Carbone, V. (2003). The changing role of ports in supply-chain management an empirical analysis. Maritime Policy and Management, 30(4), 305-320. http://dx.doi.org/10.1080/0308883032000145618

Collison, F. (1984). North to Alaska: marketing in the Pacific Northwest-Central Alaska liner trade. Maritime Policy and Management, 11(2), 99-112. http://dx.doi.org/10.1080/03088838400000003

Cronbach, L. (1951). Coefficient alpha and the internal structure of tests. Psychometrika, 16, 297-334. http://dx.doi.org/10.1007/BF02310555 
Cullinane, K. (2002). A stochastic frontier model of the efficiency of major container terminals in Asia: assessing the influence of administrative and ownership structures. Transportation Research, A(36), 743-762. http://dx.doi.org/10.1016/S0965-8564(01)00035-0

De Martino, M. (2003). The changing role of ports in supply-chain management: an empirical analysis. Maritime Policy and Management, 30(4), 305-320. http://dx.doi.org/10.1080/0308883032000145618

De Souza, G. A. (2003). Liner shipping companies and terminal operators: internationalization or globalization? Maritime Economics and Logistics, 5, 393-412.

Gray, R. (2004). A logistics and supply chain management approach to port performance measurement. Maritime Policy \& Management, 31(1), 47-67. http://dx.doi.org/10.1080/0308883032000174454

Ha, M. (2003). A comparison of service quality at major container ports: implications for Korean ports. Journal of Transport Geography, 11(1), 131-137. http://dx.doi.org/10.1016/S0966-6923(02)00069-8

Heng, W., Tongzon, J. L. (2005). Port privatization, efficiency and competitiveness: some empirical evidence from $\begin{array}{lllll}\text { container ports. } & \text { Transportation } & \text { Research, } & \text { 405-424, }\end{array}$ http://dx.doi.org.libproxy1.nus.edu.sg/10.1016/j.tra.2005.02.001

Kent, J., Parker, R., Luke, R. (2001). An empirical examination of shipper perceptions of service selection attributes in five truckload industry. Transportation Journal, 51(3), 27-36.

Lu, C., Marlow, P. (1999). Strategic groups in Taiwanese liner shipping. Maritime Policy and Management, 26(1), 1-26. http://dx.doi.org/10.1080/030888399287032

Malchow, M., Kanafani, A. (2001). A disaggregate analysis of factors influencing port selection. Maritime Policy and Management, 28(3), 265-277. http://dx.doi.org/10.1080/03088830110060840

McCalla, R. (1994). Canadian Container: How have they fares? How will they do? Maritime Policy and Management, 21(3), 207-217.

Murphy, P., Dalenberg, D., Daley, J. (1988). A contemporary perspective on international port operations. Transportation Journal, 28(1), 23-31.

Murphy, P., Dalenberg, D., Daley, J. (1989). Assessing international port operations. International Journal of Physical Distribution and Materials Management, 19(9), 3-10. http://dx.doi.org/10.1108/EUM0000000000334

Murphy, P., Dalenberg, D., Daley, J. (1991). Analysing international water transportation: the perspectives of large U.S. industrial corporations. Journal of Business Logistics, 12(1), 169-190.

Murphy, P., Daley, J., Dalenberg, D. (1992). Port selection criteria: an application of a transportation research framework. Logistics and Transportation Review, 28(3), 237.

Notteboom, T. E. (2005). Port regionalization: towards a new phase in port development. Maritime Policy \& Management, 32(3), 297-313. http://dx.doi.org/10.1080/03088830500139885

Nova'k, A., Christine, L., Abetz, L. (2004). Development and validation of an acceptability and satisfaction questionnaire for a contraceptive vaginal ring. Pharmaco Economics, 22(4), 245-256. http://dx.doi.org/10.2165/00019053-200422040-00003

Panayides, P. M. (2007). Development of ameasurement instrument for port supply chain orientation. Paper presented at the In: Proceedings of the IAME Annual Conference 2007, 2-4 July, Athens, Greece.

Pearson, R. (1980). Containerline Performance and Service Quality: University of Liverpool.

Peters, H. (1990). Structural changes in international trade and transport markets: the importance of markets. Paper presented at the The 2nd KMI International Symposium.

Robinson, R. (2002). Ports as elements in value-driven chain systems: the new paradigm. Maritime Policy and Management, 25(1), 21-40. http://dx.doi.org/10.1080/03088830210132623

Rodrigue, J. P. (2005). Port regionalization: towards a new phase in port development. Maritime Policy \& Management, 32(3), 297-313. http://dx.doi.org/10.1080/03088830500139885

Slack, B. (1985). Containerization inter-port competition and port selection. Maritime Policy and Management, 12(4), 293-303. http://dx.doi.org/10.1080/03088838500000043

Song, D. W. (2007). Development of a measurement instrument for port supply chain orientation. Paper presented at the Proceedings of the IAME Annual Conference 2007, 2-4 July, Athens, Greece.

Starr, J. (1994). The mid-Atlantic load centre: Baltimore or Hampton Road? Maritime Policy and Management, 


\section{1(3), 219-227. http://dx.doi.org/10.1080/03088839400000045}

Tracey, M. (2004). Transportation effectiveness and manufacturing firm performance. International Journal of Logistics Management, 15(2), 31-49. http://dx.doi.org/10.1108/09574090410700293

UNCTAD. (1992). Port Marketing and the Challenge of the Third Generation Port,, pp. 358-361.

Ware, J., Kosinski, M., Gandek, D. (1998). The factor structure of the health survey in 10 countries. International Quality of Life Assessment, 51, 159-165.

Willingale, M. (1981). The Port routing behaviour of short sea ship operator theory and practices. Maritime Policy and Management, 8(2), 109-120. http://dx.doi.org/10.1080/03088838100000032

Yeo, G.-T., Roe, M., Dinwoodie, J. (2008). Evaluating the competitiveness of container ports in Korea and China. Elsevier, Transportation Research . A(42), 910-921. http://dx.doi.org/10.1016/j.tra.2008.01.01

Table 1. Respondents' Profiles

\begin{tabular}{lcc}
\hline \multicolumn{1}{c}{ Gender } & Frequency & Percent \\
Male & 215 & 67.2 \\
Female & 105 & 32.8 \\
Total & 320 & 100.0
\end{tabular}

\begin{tabular}{lcc}
\multicolumn{1}{c}{ Age } & & \\
& 5 & 1.6 \\
Under 18 & 4 & 1.3 \\
$18-25$ & 129 & 40.3 \\
$26-35$ & 157 & 49.1 \\
$36-45$ & 22 & 6.9 \\
$46-55$ & 3 & 0.9 \\
More than 55 & 320 & 100.0 \\
Total & & \\
$\quad$ Educational Level & & \\
n $\quad$ - & & \\
Diploma & 15 & 4.7 \\
Associate of Art & 93 & 29.1 \\
BS & 149 & 46.6 \\
MS & 63 & 19.7 \\
Total & 320 & 100.0
\end{tabular}

Job Profiles

$\begin{array}{lcc} & 14 & 4.4 \\ \text { Manager } & 65 & 20.3 \\ \text { High Expert } & 117 & 36.6 \\ \text { Executive Expert } & 32 & 10.0 \\ \text { Port Operator } & 47 & 14.7 \\ \text { Terminal Operator } & 45 & 14.1 \\ \text { Others } & 320 & 100.0 \\ \text { Total } & & \end{array}$


Table 2. Components of Competitiveness for Shahid Rajaee port and Shipping Lines

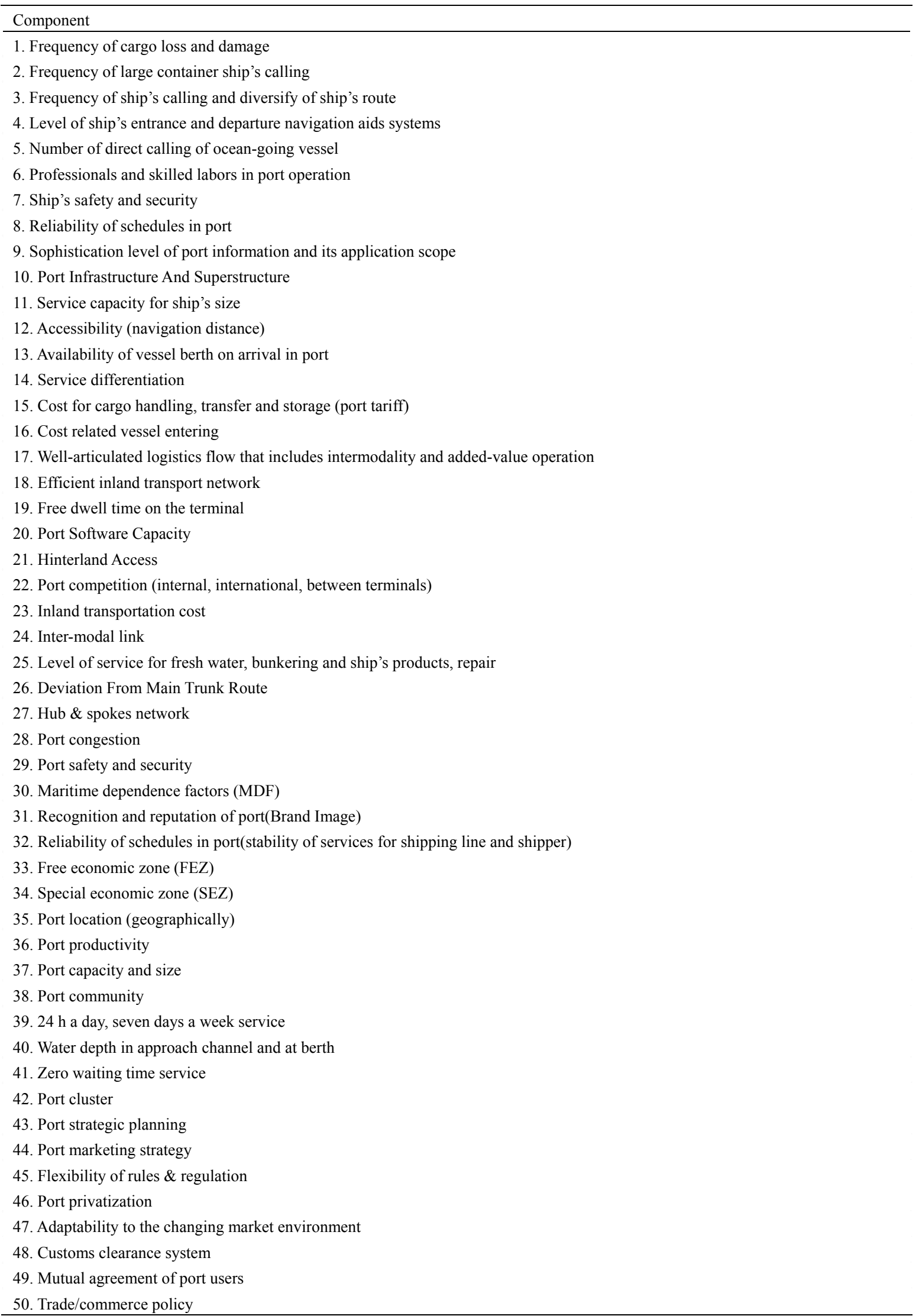


Table 3. Loadings on Each Factor Extracted from Rotated Component Matrix

\begin{tabular}{|c|c|c|c|c|c|c|c|c|}
\hline \multirow[t]{2}{*}{ Variables } & \multicolumn{8}{|c|}{ Factor } \\
\hline & 1 & 2 & 3 & 4 & 5 & 6 & 7 & 8 \\
\hline 32. Reliability of Schedules in Port & 0.703 & & & & & & & \\
\hline 36. Port Productivity & 0.695 & & & & & & & \\
\hline 31. Recognition and Reputation of Port & 0.686 & & & & & & & \\
\hline 43. Port Strategic Planning & 0.730 & & & & & & & \\
\hline 44. Port Marketing Strategy & 0.766 & & & & & & & \\
\hline 45. Flexibility of Rules \& Regulation & 0.672 & & & & & & & \\
\hline 18. Efficient Inland Transport Network & & 0.693 & & & & & & \\
\hline 23. Inland Transportation Cost & & 0.672 & & & & & & \\
\hline 20. Port Software Capacity & & 0.557 & & & & & & \\
\hline $\begin{array}{l}\text { 09. Sophistication Level of Shipping Information } \\
\text { Software and System }\end{array}$ & & 0.681 & & & & & & \\
\hline 10. Port Infrastructure And Superstructure & & 0.659 & & & & & & \\
\hline 38. Port Community & & 0.215 & & & & & & \\
\hline 27. Hub \& Spokes Network & & & 0.707 & & & & & \\
\hline 26. Deviation From Main Trunk Route & & & 0.667 & & & & & \\
\hline 28. Port Congestion & & & 0.651 & & & & & \\
\hline 08. Reliability of Schedules in Shipping & & & 0.771 & & & & & \\
\hline 07. Ship Safety and Security & & & 0.761 & & & & & \\
\hline 02. Frequency of Large Container Ship Calling & & & 0.414 & & & & & \\
\hline 14. Service Differentiation & & & & 0.787 & & & & \\
\hline 13. Availability of Vessel Berth on Arrival in Port & & & & 0.783 & & & & \\
\hline $\begin{array}{l}\text { 17. Well Articulated Logistics Flow and Added-Value } \\
\text { Operation }\end{array}$ & & & & 0.277 & & & & \\
\hline 12. Port Accessibility (Navigation Distance) & & & & 0.803 & & & & \\
\hline 11. Ship Capacity and Size & & & & 0.777 & & & & \\
\hline 22. Port Competition & & & & 0.273 & & & & \\
\hline $\begin{array}{l}\text { 03. Frequency of Ships Calling and Diversify of Ship } \\
\text { Route }\end{array}$ & & & & & 0.669 & & & \\
\hline 01. Frequency of Cargo Loss and Damage & & & & & 0.729 & & & \\
\hline $\begin{array}{l}\text { 05. Number of Direct Shipping Lines of Ocean-Going } \\
\text { Vessel }\end{array}$ & & & & & 0.437 & & & \\
\hline 40. Water Depth in Approach Channel and at Berth & & & & & 0.779 & & & \\
\hline 37. Port Capacity and Size & & & & & 0.526 & & & \\
\hline 42. Port Cluster & & & & & 0.350 & & & \\
\hline 35. Port Location (Geographically) & & & & & & 0.758 & & \\
\hline 34. Special Economic Zone (SEZ) & & & & & & 0.380 & & \\
\hline 33. Free Economic Zone (FEZ) & & & & & & 0.312 & & \\
\hline 15. Cost for Cargo Handling, Transfer and Storage & & & & & & 0.729 & & \\
\hline 24. Inter-Modal Link & & & & & & 0.571 & & \\
\hline 16. Cost Related Vessel Entering & & & & & & 0.547 & & \\
\hline 50. Trade and Commerce Policy & & & & & & & 0.737 & \\
\hline 49. Mutual Agreement of Port Users & & & & & & & 0.563 & \\
\hline 47. Adaptability to the Changing Market Environment & & & & & & & 0.268 & \\
\hline $\begin{array}{l}\text { 25. Level of Service for Fresh Water, Bunkering, Ship } \\
\text { products and Repair }\end{array}$ & & & & & & & 0.659 & \\
\hline 19. Free Dwell Time on the Terminal & & & & & & & 0.654 & \\
\hline 30. Maritime Dependence Factors (MDF) & & & & & & & 0.294 & \\
\hline 48. Customs Clearance System & & & & & & & & 0.780 \\
\hline 39. 24 Hour a Day, Seven Days a Week Service & & & & & & & & 0.629 \\
\hline 41. Zero Waiting Time Service & & & & & & & & 0.224 \\
\hline 04. Level of Ship Entrance and Departure & & & & & & & & 0.695 \\
\hline 21. Hinterland Access & & & & & & & & -0.457 \\
\hline $\begin{array}{l}\text { 06. Professionals and Skilled Labors in Shipping } \\
\text { Operation }\end{array}$ & & & & & & & & -0.210 \\
\hline
\end{tabular}


Table 4. Loadings on Each Factor Extracted from Rotated Component Matrix

\begin{tabular}{lc}
\hline Variables & Cronbach's $\alpha$ \\
\hline Port Strategy and Policy & 0.874 \\
Port Logistics & 0.842 \\
Hinterland Condition & 0.698 \\
Availability & 0.769 \\
Shipping Maritime Service & 0.759 \\
Port Regional Service & 0.798 \\
Shipping Agreement & 0.753 \\
Port Service and Connectivity & 0.737 \\
\hline
\end{tabular}

Table 5. Correlations with Pearson Coefficient

\begin{tabular}{|c|c|c|c|c|c|c|c|c|c|}
\hline & & $\begin{array}{c}\text { Port } \\
\text { Strategy } \\
\text { Policy } \\
\end{array}$ & $\begin{array}{c}\text { Port } \\
\text { Logistics }\end{array}$ & $\begin{array}{l}\text { Hinterland } \\
\text { Condition }\end{array}$ & Availability & $\begin{array}{c}\text { Shipping } \\
\text { Maritime } \\
\text { Service }\end{array}$ & $\begin{array}{c}\text { Port } \\
\text { Regional } \\
\text { Service }\end{array}$ & $\begin{array}{c}\text { Shipping } \\
\text { Agreement }\end{array}$ & $\begin{array}{c}\text { Port Service } \\
\text { And } \\
\text { Connectivity }\end{array}$ \\
\hline $\begin{array}{l}\text { Port Strategy } \\
\text { Policy }\end{array}$ & $\begin{array}{c}\text { Pearson Cor. } \\
\text { Sig. (2-tailed) } \\
\text { N }\end{array}$ & $\begin{array}{c}1 \\
320 \\
\end{array}$ & & & & & & & \\
\hline Port Logistics & $\begin{array}{c}\text { Pearson Cor. } \\
\text { Sig. (2-tailed) } \\
\mathrm{N}\end{array}$ & $\begin{array}{c}0.485^{* *} \\
0.000 \\
320 \\
\end{array}$ & $\begin{array}{c}1 \\
320 \\
\end{array}$ & & & & & & \\
\hline $\begin{array}{l}\text { Hinterland } \\
\text { Condition }\end{array}$ & $\begin{array}{c}\text { Pearson Cor. } \\
\text { Sig. (2-tailed) } \\
\mathrm{N}\end{array}$ & $\begin{array}{c}0.365^{* *} \\
0.000 \\
320 \\
\end{array}$ & $\begin{array}{c}0.501 * * \\
0.000 \\
320 \\
\end{array}$ & $\begin{array}{c}1 \\
320 \\
\end{array}$ & & & & & \\
\hline Availability & $\begin{array}{c}\text { Pearson Cor. } \\
\text { Sig. (2-tailed) } \\
\text { N }\end{array}$ & $\begin{array}{c}0.370^{* *} \\
0.000 \\
320 \\
\end{array}$ & $\begin{array}{c}0.590 * * \\
0.000 \\
320\end{array}$ & $\begin{array}{c}0.407 \\
0.000 \\
320 \\
\end{array}$ & $\begin{array}{c}1 \\
320 \\
\end{array}$ & & & & \\
\hline $\begin{array}{l}\text { Shipping } \\
\text { Maritime } \\
\text { Service }\end{array}$ & $\begin{array}{l}\text { Pearson Cor. } \\
\text { Sig. (2-tailed) } \\
\text { N }\end{array}$ & $\begin{array}{c}0.410^{* *} \\
0.000 \\
320\end{array}$ & $\begin{array}{c}0.353 * * \\
0.000 \\
320\end{array}$ & $\begin{array}{c}0.310^{* * *} \\
0.000 \\
320\end{array}$ & $\begin{array}{c}0.298 * * \\
0.000 \\
320\end{array}$ & $\begin{array}{c}1 \\
320 \\
\end{array}$ & & & \\
\hline $\begin{array}{c}\text { Port Regional } \\
\text { Service }\end{array}$ & $\begin{array}{c}\text { Pearson Cor. } \\
\text { Sig. (2-tailed) } \\
\mathrm{N}\end{array}$ & $\begin{array}{c}0.131^{*} \\
0.019 \\
320 \\
\end{array}$ & $\begin{array}{c}0.400^{* *} \\
0.019 \\
320 \\
\end{array}$ & $\begin{array}{c}-0.004 \\
0.937 \\
320 \\
\end{array}$ & $\begin{array}{c}-0.064 \\
0.252 \\
320 \\
\end{array}$ & $\begin{array}{c}0.144 * * \\
0.010 \\
320 \\
\end{array}$ & $\begin{array}{r}1 \\
320 \\
\end{array}$ & & \\
\hline $\begin{array}{c}\text { Shipping } \\
\text { Agreement }\end{array}$ & $\begin{array}{c}\text { Pearson Cor. } \\
\text { Sig. (2-tailed) } \\
\mathrm{N}\end{array}$ & $\begin{array}{c}.400 * * \\
0.019 \\
320 \\
\end{array}$ & $\begin{array}{c}0.216^{* *} \\
0.000 \\
320 \\
\end{array}$ & $\begin{array}{c}0.209 * * \\
0.000 \\
320\end{array}$ & $\begin{array}{c}0.224^{* *} \\
0.000 \\
320 \\
\end{array}$ & $\begin{array}{c}0.273^{* *} \\
0.000 \\
320 \\
\end{array}$ & $\begin{array}{c}0.182 * * \\
0.001 \\
320 \\
\end{array}$ & $\begin{array}{c}1 \\
320 \\
\end{array}$ & \\
\hline $\begin{array}{l}\text { Port Service } \\
\text { and } \\
\text { Connectivity }\end{array}$ & $\begin{array}{l}\text { Pearson Cor. } \\
\text { Sig. (2-tailed) } \\
\text { N }\end{array}$ & $\begin{array}{c}0.304 * * \\
0.000 \\
320\end{array}$ & $\begin{array}{c}0.355^{* *} \\
0.000 \\
320\end{array}$ & $\begin{array}{c}0.326 * * \\
0.000 \\
320\end{array}$ & $\begin{array}{c}0.249 * * \\
0.000 \\
320\end{array}$ & $\begin{array}{c}0.308 * * \\
0.000 \\
320\end{array}$ & $\begin{array}{c}0.163 * * \\
0.003 \\
320\end{array}$ & $\begin{array}{c}0.246^{* *} \\
0.000 \\
320\end{array}$ & $\begin{array}{c}1 \\
320\end{array}$ \\
\hline
\end{tabular}




\section{Sea Port System}

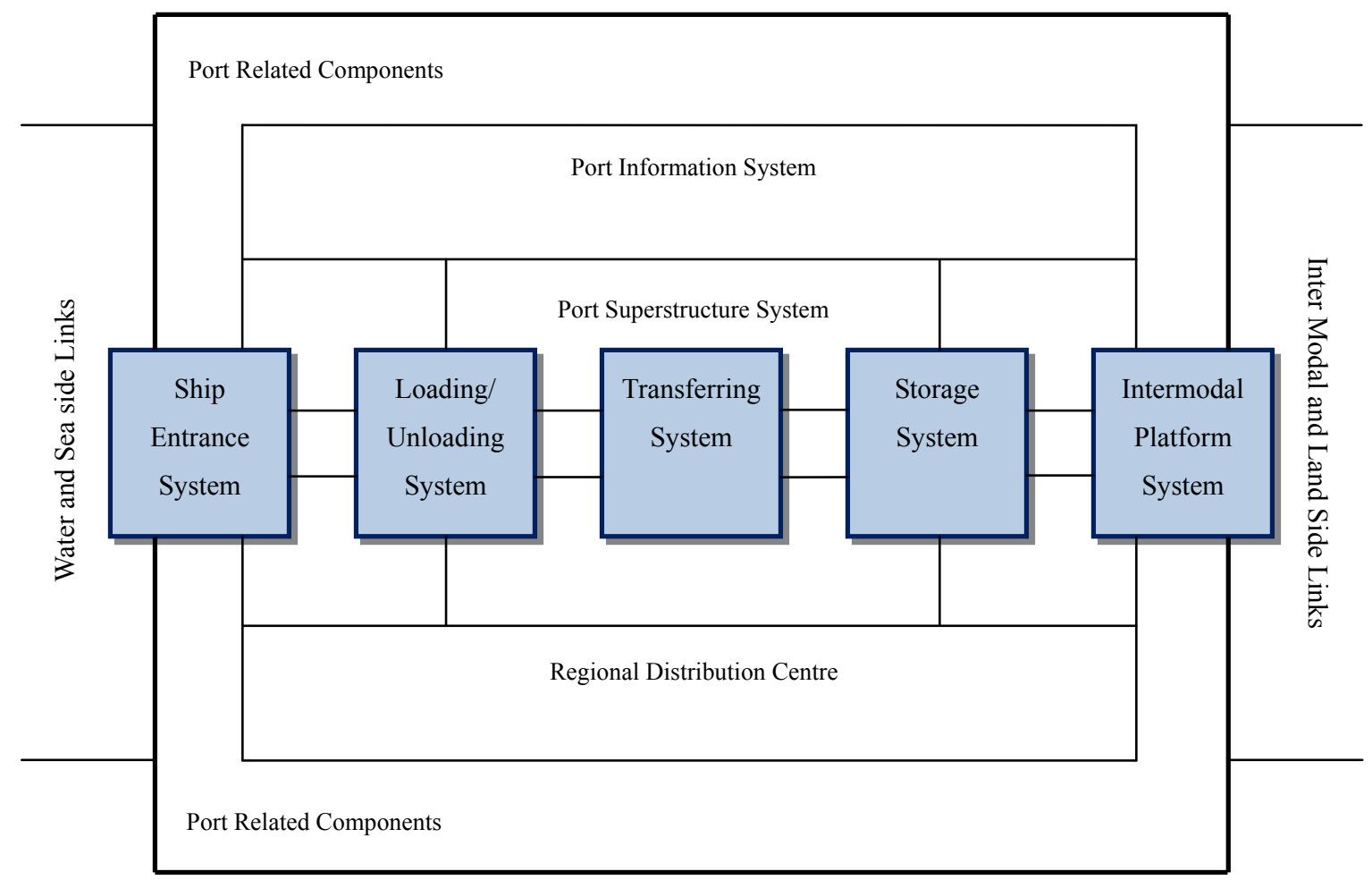

Figure 1. Selection of Determinants of Competitiveness of Port and Shipping Lines (Gi-Tae Yeo, 2008) 


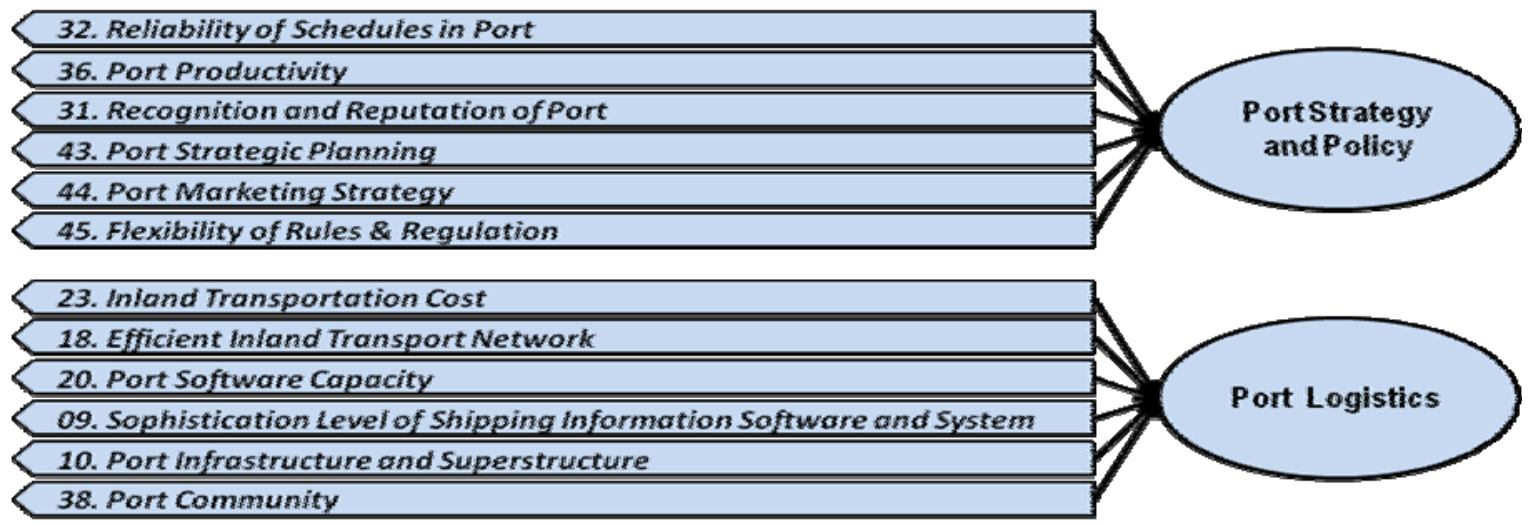

27. Hub \& Spokes Network

26. Deviation from main trunk Route

28. Port Congestion

08. Reliability of Schedules in Shipping

07. Ship Safety and Security

02. Frequency of Large Cantainer Ship Calling

14. Service Differentiation

13. Availability of Vessel Berth on Arrival in Port

17. Well Articulated Logistics Flow and added-value operation

12. Port Accessibility (Navigation Distance)

11. Ship Capacity and Size

22. Port Competition

03. Frequency of Ships Calling and Diversify of Ship Route

01. Frequency of Cargo Loss and Damage

05. Number of Direct Shipping Lines of Ocean-Going Vessel

40. Water Depth in Approach Channel and at Berth

42. Port Cluster

37. Port Capacity and Size

35. Port Location (Geographically)

34. Special Economic Zone (SEZ)

33. Free Economic Zone (FEZ)

15. Cost for Cargo Handling, Transfer and Storage

16. Cost Related Vessel Entering

24. Inter-Modallink

50. Trade and Commerce Policy

49. Mutual Agreement of Port Users

47. Adaptability to the Changing Market Environment

25. Level of Service for Fresh Water, Bunkering, Ship products and Repair

19. Free Dwell Time on the Terminal

30. Maritime Dependence Factors (MDF)

39. 24 Hour a Day, Seven Days a Week Service

48. Customs Clearance System

41. Zero Waiting Time Service

04. Level of Ship Entrance and Departure Navigation Aids Systems

21. Hinteriand Access

06. Professionals and Skilled Labors in Shipping Operation

PortRegional Center

Shipping

Maritime

Service
Hinterland

Condition

Availability

Figure 2. Proposed Model for Evaluating of Port Competitiveness Marketing Strategy 